\title{
First report of an endemic Australian thrips, Thrips australis (Thysanoptera: Thripidae) on Eucalyptus in Shiraz, Iran
}

\author{
K. Minaei
}

Department of Plant Protection, College of Agriculture, Shiraz University, Shiraz, Iran

\begin{abstract}
The gum tree thrips, Thrips australis (Bagnall) is recorded from Shiraz, Fars province, Iran for the first time. Variation in color and structure of species is discussed and illustrations are provided.
\end{abstract}

\section{Introduction}

The genus Thrips Linnaeus is the second largest genus in the Thysanoptera, and currently includes 286 species worldwide (Mound, 2012). However the genus is absent from the Neotropics, apart from introduced species (Mound and Marullo, 1996). Most species in the genus are flower living, although a few are known to breed on leaves (Mound, 1997; Mound and Kibby, 1998). Some members of the genus are well known as pests in various parts of the world, such as T. angusticeps Uzel, T. flavus Schrank, T. hawaiiensis (Morgan), T. meridionalis Priesner, T. tabaci Lindeman (Moritz et al., 2004) as well as Iran (Minaei et al., 2007). However, for many species there is little information available on their biology, geographical distributions, host associations and structural variation.

Correspondence: Kambiz Minaei, Department of Plant Protection, College of Agriculture, Shiraz University, Shiraz, Iran.

E-mail:kminaei@shirazu.ac.ir

Key words: Thrips australis, Eucalyptus camaldulensis, Fars province, new record.

Acknowledgements: during my visit to CSIRO Ecosystem Sciences, Canberra, Australia in 2009, Dr. Laurence Mound, encouraged me to collect T. australis from Eucalyptus trees in Iran. He also kindly gave me a slide mount of the species at that time. Dr. Ahmad Reza Khosravi, Depatment of Biology, Shiraz University kindly recognized the species of Eucalyptus.

Received for publication: 16 July 2012.

Revision: not required.

Accepted for publication: 27 August 2012.

(C) Copyright K. Minaei, 2012

Licensee PAGEPress, Italy

Journal of Entomological and Acarological Research 2012; 44:e9

doi:10.4081/jear.2012.e9

This article is distributed under the terms of the Creative Commons Attribution Noncommercial License (by-nc 3.0) which permits any noncommercial use, distribution, and reproduction in any medium, provided the original author(s) and source are credited.
Recent years have seen much study into the genus Thrips. The species of Thrips from the Indian region were revised and 33 species were recognized in that area (Bhatti, 1980). Palmer (1992) has given identification keys to 91 species from Oriental and Pacific islands. Nakahara (1994) has treated 62 species from the New World. A key is provided for 8 species from Central America (Mound and Marullo, 1996). Ten pest species of the genus have been treated and a key has been given by Mound and Kibby (1998). Mound and Masumoto (2005) provided an identification key to 41 species from Australia, New Zealand and New Caledonia. An illustrated key is provided to 23 species of the genus Thrips from Peninsular Malaysia (Mound and Azidah, 2009). Thirty-four species are recorded from Africa (Mound, 2010) and subsequently an illustrated key is provided to distinguish the 33 species of genus Thrips recorded from China (Zhang et al., 2011). Finally, an Internet based interactive key has been prepared for 26 species of this genus, including potential invaders from California, North America (Hoddle et al., 2012). In Iran, 26 species of the genus are listed (Table 1) (Bhatti et al., 2009), although the names of two of them, T. iranicus and T. pistaciae, remain in doubt because they cannot be recognized from their original descriptions. The purpose of this paper is to report another Thrips species from Iran, with illustrations and observed variations within the Iranian specimens.

\section{Materials and methods}

The specimens of Thrips australis discussed below were collected in Shiraz, Fars province, Iran, by breaking up white flowers of Eucalyptus camaldulensis onto a plastic tray. The specimens were removed with a fine brush into a collecting vial containing 95\% ethyl alcohol. Microscopic slides were mounted into Canada Balsam after dehydration through a series of ethanol using a form of the protocol given in World Thysanoptera (http:/anic.ento.csiro.au/thrips/field_lab/index. html).

Microphotographs were obtained using a Dino-Lite Microscope, Eyepiece Camera. Digital images were enhanced and plates prepared using Adobe Photoshop ${ }^{\mathrm{TM}}$. Terminology generally follows Mound et al., (1976) and Mound and Masumoto (2005).

Most specimens are deposited at the Department of Plant Protection Collection, Shiraz University, Shiraz, Iran.

\section{Results}

\section{Thrips australis (Bagnall)}

Isoneurothrips australis Bagnall, 1915 (p. 592)

Thrips lacteicorpus Girault, 1926 (p. 17)

Thrips mediolineus Girault, 1926 (p. 18)

Anomalothrips amygdali Morgan, 1929 (p. 5)

Isoneurothrips marisabelae Ortiz, 1973 (p. 119) 
Specimens of this species were collected from the white flowers of Eucalyptus camaldulensis at Shiraz and this is the first report of T. australis in Iran. The specimens were compared with one specimen of this species from New Zealand, and also with the available published literature. Although variation in color and structure was observed within the Iranian specimens (Tables 1 and 2), they were distinguishable from other Thrips species by almost a complete row of forewing (Figure 1A), six (instead of five) marginal setae on clavus (Figure 1A), and a bullet shaped antennal segment VI (Figure 1B).

\section{Diagnosis}

\section{Macropterous}

Body typically yellow usually with brown markings medially on tergites III-VIII, tergites IX-X brown; antennal segment I white, II-III brownish yellow (sometimes I-II white, III brownish yellow, remaining segments almost brown; forewing usually shaded; major setae except ocellars and postoculars dark. Antennae 7-segmented (Figure 1C), IIIIV with forked sensorial, VI large and bullet-shaped, VII short (Figure 1B). The head is bigger in width than in length (Figure 1D) with ocellar setae III arising within ocellar triangle. Pronotum with 2 pairs of short stout postero-angular setae (Figure 1D); posterior margin with 6 , 7 or 8 setae. Mesonotum with lines of sculpture close to campaniform sensilla. Metanotum reticulate medially (Figure 1E), median setae arise behind anterior margin, campaniform sensilla present. Forewing

Table 1. Thrips species recorded in Iran.

\begin{tabular}{|c|c|}
\hline No. & Thrips species \\
\hline 1 & Thrips albopilosus Uzel \\
\hline 2 & Thrips angusticeps Uzel \\
\hline 3 & Thrips atratus Haliday \\
\hline 4 & Thrips coloratus Schmutz \\
\hline 5 & Thrips dubius Priesner \\
\hline 6 & Thrips euphorbiae Knechtel \\
\hline 7 & Thrips flavus Schrank \\
\hline 8 & Thrips fraudulentus (Priesner) \\
\hline 9 & Thrips fuscipennis Haliday \\
\hline 10 & Thrips hawaiiensis (Morgan) \\
\hline 11 & Thrips iranicus Yakhontov \\
\hline 12 & Thrips major Uzel \\
\hline 13 & Thrips mareoticus (Priesner) \\
\hline 14 & Thrips meridionalis (Priesner) \\
\hline 15 & Thrips minutissimus Linnaeus \\
\hline 16 & Thrips nigropilosus Uzel \\
\hline 17 & Thrips pelikani Schliephake \\
\hline 18 & Thrips physapus Linnaeus \\
\hline 19 & Thrips pillichi Priesner \\
\hline 20 & Thrips pistaciae Yakhontov \\
\hline 21 & Thrips simplex (Morison) \\
\hline 22 & Thrips tabaci Lindeman \\
\hline 23 & Thrips trehernei Priesner \\
\hline 24 & Thrips verbasci (Priesner) \\
\hline 25 & Thrips vuilleti (Bagnall) \\
\hline 26 & Thrips vulgatissimus Haliday \\
\hline
\end{tabular}

first vein with almost uninterrupted row of setae, clavus with 6 marginal and 1 discal setae (Figure 1A). Abdominal tergite II with 4 lateral setae, tergites V-VIII with paired ctenidia, marginal comb not developed medially on tergite VIII (Figure 1F); IX with 2 pairs of campaniform sensilla; pleurotergites commonly with more than 5 discal setae (Figure 1G). Sternite II with 2 pairs of marginal setae, III-VII with 3 pairs. Sternites with a large number of discal setae (Figure 1H); the number of setae increased toward sternites VII; 3 small setae (sometimes 2 or 4) on sternite II but 14-32 developed setae on sternite VII, in irregular double rows (Figure 1H).

MATERIAL EXAMINED. 7 females, Iran, Fars province, Shiraz, from Eucalyptus camaldulensis, 21.06.2012 (KM853); 15 females, same locality, from Eucalyptus camaldulensis, 24.06.2012 (KM856); 17 females, Shiraz, from Eucalyptus camaldulensis, 24.06.2012 (KM861).

\section{Discussion and Conclusions}

Although the species is native to Australia, it has been introduced around the world wherever Eucalyptus trees are grown (Mound, 2010). So it seems likely that the presence of this species in Iran is not surprising. Color and size both vary, and as a result the species has been described under five other names (see above). The variation in color of antennal segments and two character states reported here (Table 2), as well as some other variations which have already been mentioned above (Diagnosis section), support the variability of the species. In addition to Australia (Mound and Masumoto, 2005), Thrips australis has been recorded from many other parts of the world, including Egypt (Priesner, 1965), Japan (Miyazaki and Kudo, 1988), the Pacific regions (Palmer, 1992), Europe (zur Strassen, 2003), United States (Nakahara, 1994), Central America (Mound and Marullo 1996), Brazil (Monteiro, 2002), Peninsular Malaysia (Mound and Azidah, 2009), Africa (Mound, 2010), Britain (Collins, 2010), China (Zhang et al., 2011) and North America (Hoddle et al., 2012). Sakimura (1967) and Kirk (1987) have questioned whether T. australis is native to Australia on the basis that this species has been found in so many countries around the world. However, neither of these authors considered the many field observations that associate this thrips with white Eucalyptus flowers, both in Australia and in other countries (Mound and Masumoto, 2005). In Kenya, T. australis is known from crops such as tomato, capsicum, French bean, sunflower and carrot (Icipe, 2012). However, there are currently no records from any crops in Iran.

Table 2. Variation in color and structure of among 39 specimens of T. australis collected in Shiraz.

\begin{tabular}{lcc} 
Character & Characteristics & $\begin{array}{c}\text { Number } \\
\text { of specimens }\end{array}$ \\
Color of antennal & I-II white, III brownish yellow & 13 \\
segments $^{*}$ & I white, II-III brownish yellow & 26 \\
Number of posteromarginal & 6 & 20 \\
setae on pronotum & 7 & 11 \\
& 8 & 8 \\
\hline Number of discal setae & 2 & 14 \\
on sternites II & 3 & 18 \\
& 4 & 7 \\
\hline
\end{tabular}

${ }^{*}$ Antennal segments IV-VII in all specimens brown. 

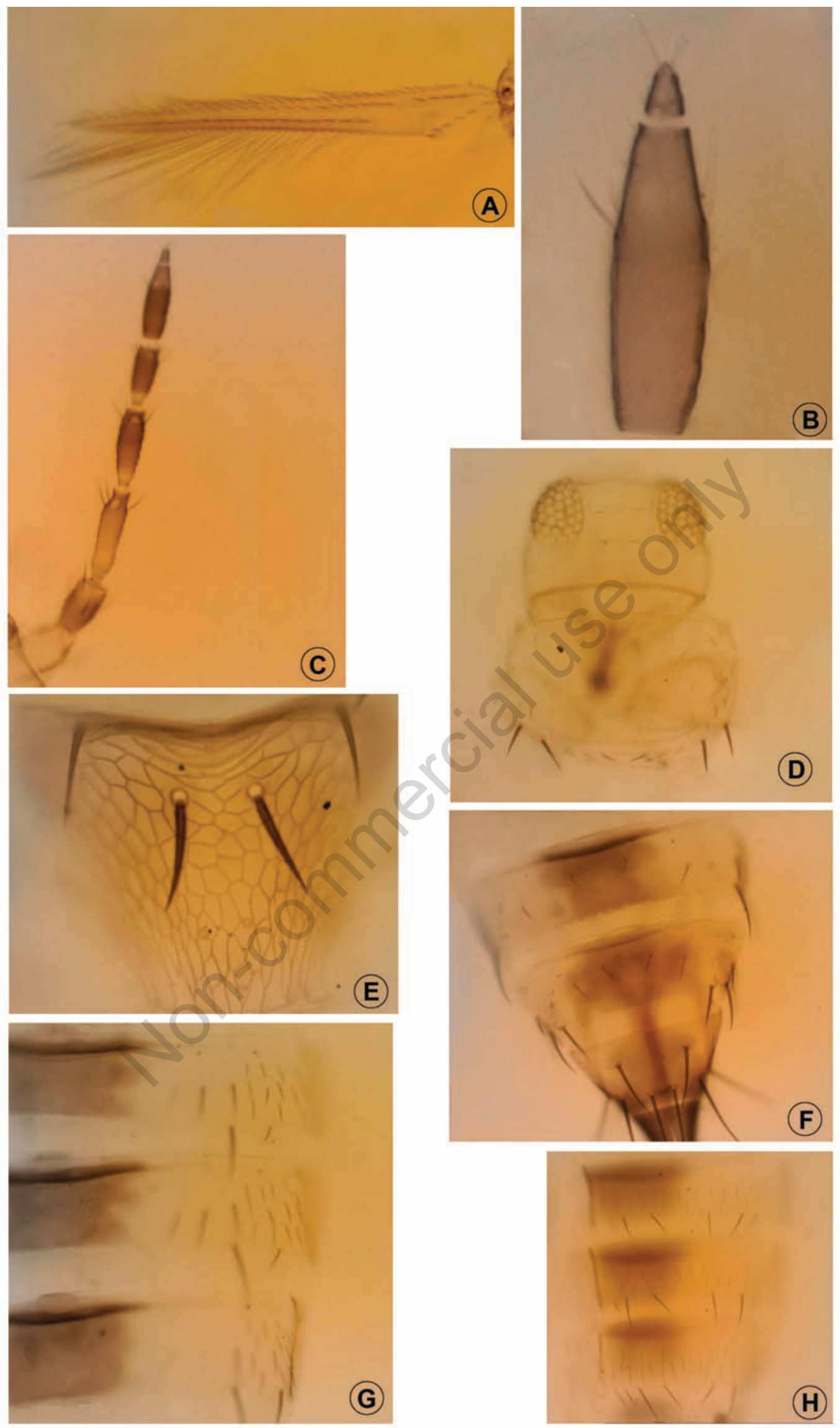

Figure 1. T. australis (A) forewing; (B) antennal segments VI-VII; (C) left antenna; (D) head and pronotum; (E) metanotum; (F) abdominal tergites VII-IX; (G) abdominal pleurotergites IV-VI; (H) abdominal sternites V-VII. 


\section{References}

BAGNALL R.S., 1915 - Brief descriptions of new Thysanoptera. VI. Ann. Mag. Nat. Hist. 15: 588-597.

BHATTI J.S., 1980 - Species of the genus Thrips from India. Syst. Entomol. 5: 109-166.

BHATTI J.S., ALAVI J., ZUR STRASSEN R., TELMADARRAIY Z., 2009 Thysanoptera in Iran 1938-2007. An overview. Part 1. Thrips. 7: 182.

COLLINS D.W., 2010 - Thysanoptera of Great Britain: a revised and updated checklist. Zootaxa. 2412: 21-41.

GIRAULT A.A., 1926 - Three new Thysanoptera from Australia. Insecut. Inscit. Menstr. 14: 17-18.

HODDLE M.S., MOUND L.A., PARIS D., 2012 - Thrips of California 2012. http://keys.lucidcentral.org/keys/v3/thrips_of_california/Thrips_of_ California.html Accessed: 12.07.2012.

ICIPE 2012 - Occurrence of Thrips australis Hood, 1915 in East Africa. http://thrips.icipe.org/index.php?option=com_content\&view=article\&id=131\&Itemid=156 Accessed: 30.06 .2012 .

KIRK, W.D.J., 1987 - A key to the larvae of some common Australian flower thrips (Insecta: Thysanoptera), with a host-plant survey. Aust. J. Zool. 35: 173-185.

MINAEI K., AZEMAYESHFARD P., MOUND L.A., 2007 - The Thrips genus-group (Thysanoptera: Thripidae) in Iran. J. Entomol. Soc. Iran. 27: 29-36.

MIYAZAKI, M., KUDO, I., 1988 - Bibliography and host plant catalogue of Thysanoptera of Japan. Misc. Publ. Natl. Inst. Agro-Environ. Sci. 3: $1-246$.

MORGAN A.C., 1929 - A new genus and five new species of Thysanoptera foreign to the United States. Proc. Entomol. Soc. Wash. 31: 1-9.

MORITZ G., MOUND L.A., MORRIS D.C., GOLDARAZENA A., 2004 - Pest thrips of the world - visual and molecular identification of pest thrips. Cd-rom. Brisbane: CBIT.

MOUND L.A., 1997 - Biological diversity. In: Lewis T, (ed). Thrips as crop pests. CAB International, Wallingford, UK: 197-215.
MOUND L.A., 2010 - Species of the Genus Thrips (Thysanoptera, Thripidae) from the Afro-tropical Region. Zootaxa. 2423: 1-24.

MOUND L.A., 2012- Thysanoptera (Thrips) of the World - a checklist. http:/www.ento.csiro.au/thysanoptera/worldthrips.html Accessed: 13.07.2012.

MOUND L.A., AZIDAH A.A., 2009 - Species of the genus Thrips (Thysanoptera) from Peninsular Malaysia, with a checklist of recorded Thripidae. Zootaxa. 2023: 55-68.

MOUND L.A., KIBBY G., 1998 - Thysanoptera: an identification guide. $\mathrm{CAB}$ International Institute of Entomology and British Museum (Natural History), London, UK: 70.

MOUND L.A., MARULLO R., 1996 - The Thrips of Central and South America: an introduction. Mem. Entomol. Int. 6:1-488.

MOUND L.A., MASUMOTO M., 2005 - The genus Thrips (Thysanoptera, Thripidae) in Australia, New Caledonia and New Zealand. Zootaxa. 1020: 1-64.

MOUND L.A., MORISON G.D., PITKIN B.R., PALMER J.M., 1976 Thysanoptera. Handbooks for the Identification of British Insects, vol. 1. Royal Entomological Society of London (RES), London, UK: 1-79.

NAKAHARA S., 1994 - The genus Thrips Linnaeus (Thysanoptera, Thripidae) of the New World. US Depart. Agr. Tech. Bull. 1822: 1183.

ORTIZ M.P., 1973 - Una nueva species de Isoneurothips Bagnall (Thysanoptera: Thripidae) del Perù. Rev. Peruana Entomol. 16: 117-120.

PALMER J.M., 1992 - Thrips from Pakistan to the Pacific: a review. Bull. Brit. Mus. Nat. Hist. (Entomol.) 61: 1-76.

PRIESNER H., 1965 - A Monograph of the Thysanoptera of the Egyptian deserts. Pub. Inst. Desert Egypte 13: 1-549.

SAKIMURA K., 1967 - A preliminary review of the genus Isoneurothrips and the subgenus Thrips (Isothrips). Pac. Insects 9: 429-436.

ZHANG H., XIE Y., LI Z., 2011 - Identification key to species of Thrips genus from China (Thysanoptera, Thripidae), with seven new records. Zootaxa. 2810: 37-46.

ZUR STRASSEN R., 2003 - Die Terebranten Thysanopteren Europas und des Mittelmeer-Gebietes. Die Tierwelt Deutschlands 74: 1-271. [Article in German]. 